\title{
NONVERBAL CREATIVITY IN TECHNICAL EDUCATION AND ITS INFLUENCE ON THE SCHOOL MANAGEMENT
}

\section{Jarmila HONZÍKOVÁ}

\begin{abstract}
This article deals with the research of creative skills within the project Nonverbal creativity in technical education carried out within the scope of grant GAČR 406/07/0109. This project deals with the research of nonverbal creativity and at the same time it will try to show how to develop the creativity in technically oriented subjects at work with the school education programme.
\end{abstract}

Key words: technical education, nonverbal creativity.

\section{NEVERBÁLNÍ TVOŘIVOST V TECHNICKÉM VZDĚLÁVÁNÍ A JEJÍ VLIV NA MANAGEMENT ŠKOL}

\begin{abstract}
Resumé: Článek pojednává o výzkumu tvořivých schopností v rámci projektu Nonverbální tvořivost $v$ technické výchově uskutečňovaného v rámci grantu GAČR 406/07/0109. Tento projekt se zabývá nejen výzkumem samotné neverbálni tvořivosti, ale zároveň se pokusí ukázat jak tuto tvořivost rozvijet $v$ technicky orientovaných predmětech při práci se školním vzdělávacím programem.
\end{abstract}

Kličcová slova: technické vzdělávání, neverbální tvořivost.

\section{Introduction}

Our society has gone through many social and economic changes during the recent years change of ownership relations, work and family environment, but also the change in the system of social values. All this put many people to situations that require different way of thinking and other techniques than those used in the past. In conjunction with the change of social background, there is also a change of work style at our schools. The schools management is changing too. In fact, the teachers prepare their students to life in the society and we do not exactly know today what kind of demands and skills will be required from the students in the near future. However, the importance of creative thinking in all kinds of human activity is rising. At the time of scientific and technical development, it is clear that the next development is heading toward difficult and complicated creative activity concerning practically all of us.

Nowadays, the creativity and creative thinking development are becoming one of the main teaching goals of the education programmes in all kinds of schools. The importance of creative thinking in educational process also highlight our Slovak colleagues (Cagáňová, Rusková) by the claiming that creative thinking techniques make educational process more effective and spport creative potential of young people in the sense of originality and innovation. One of the questions under debate in the field of creativity is how to improve its standard. When testing the creative skills, people usually use bibliographic and personal questionnaires, nontesting methods, dialogue, projective techniques, appraisal of creative activity and products, questionnaires for creative atmosphere factors, testing batteries and multidimensional projects, experimental and research methods for specific topics or different identification means (e.g. test of productive thinking, test of scientific thinking, test for creative types defining etc.). Stability, consistence and reliability of test results can be influenced by the fact that the very manifestation of creativity is dependant on many other factors e.g. emotional or physical condition, atmosphere in the group, motivation and many other often incidental effects. Tests of creative thinking and creative skills are often very demanding as to the research workers. The tests require considerable experience in searching for a suitable test, selection of reliable criteria when evaluating and interpreting the final results. These results can present the starting point for creating new curriculum and school educational programmes. They also show the creative skills level of individual age groups and what field we should concentrate on.

Within the project Nonverbal creativity in technical education, there was a research carried out by the Department of Technical Education, which is a part of the Faculty of education within the University of West Bohemia in Pilsen (Czech 
Republic). This project included transversal research of creative skills at elementary schools. Main aim of this research was to map the level of technical imagination with the help of Construction and shape test and the level of creative thinking with the help of Torrance Figural Test of Creative Thinking.

Now, let us introduce the organisation and its research results in short.

\section{Creative skills research \\ Research goals and hypotheses}

In compliance with the research goal, we raised the fundamental questions of the research:

I. Is there any connection between the results reached in Torrance Figural Test of Creative Thinking and the results reached in the Test of technical imagination Construction and shape test?

II. Has the respondents' age factor any influence on the final score of the Torrance tests?

III. Has the respondents' age factor any influence on the final score of technical imagination?

IV. Is there any significant difference in reaching both tests results with the students of $1^{\text {st }}$ stage and $2^{\text {nd }}$ stage of elementary schools?

V. Are there any significant differences in the results reached in both tests within the academic groups?

\section{Hypotheses}

For solving the creative skills research, we formulated these hypotheses:

$\mathrm{H}_{1}$ : There is a significant difference between the results reached with the Torrance figural test of creative thinking and the results reached with the test of technical imagination - construction and shape test - in all integrated groups.

$\mathrm{H}_{2}$ : Respondent's age factor has effect on the reached final score in the Torrance figural test of creative thinking.

$\mathrm{H}_{3}$ : Respondent's age factor has effect on the reached final score in the test of technical imagination - construction and shape test.

$\mathrm{H}_{4 \mathrm{a}}$ : There is a significant difference in the results reached in the test of technical imagination - construction and shape test between the students of $1^{\text {st }}$ and $2^{\text {nd }}$ stage of elementary schools.

$\mathrm{H}_{4 \mathrm{~b}}$ : There is a significant difference in the results reached in the Torrance figural test of creative thinking between the students of $1^{\text {st }}$ and $2^{\text {nd }}$ stages of elementary schools.

$\mathrm{H}_{4 \mathrm{c}}$ : There is a significant difference in the results reached in both used tests between the students of $1^{\text {st }}$ and $2^{\text {nd }}$ stages of elementary schools.

$\mathrm{H}_{5 \mathrm{a}}$ : There is a difference in the results reached in the test of technical imagination construction and shape test - between the academic groups.

$\mathrm{H}_{5 \mathrm{~b}}$ : There is a difference in the results reached in the Torrance figural test of creative thinking between the academic groups.

$\mathrm{H}_{5 \mathrm{c}}$ : There is a difference in the results reached in both used tests between the academic groups.

\section{Research organisation and research sample characteristics}

Research organisation and research sample characteristics

The research was carried out at elementary schools in Pilsner, Usti and Ceske Budejovice region. 603 pupils of the $1^{\text {st }}$ stage from five elementary schools were involved in the research. For more consistent view on the given task, there were also additional groups which were involved in the research. These were the students of the $2^{\text {nd }}$ stage within elementary schools, students of faculties of education, elementary school teachers and free time pedagogues. On the whole, there were about 1500 respondents.

\section{Research realisation timetable}

Field research study started in February 2007 and finished in March 2008. During this period, the research workers were testing the respondents by creativity tests. They also monitored the research progress and reported research data that were consequently evaluated and statistically processed.

\section{Research methods}

When gathering data, we used standardized tests of creativity:

- Construction and shape test for identification of technical imagination level, 
- Torrance figural test of creative thinking for identification of creative thinking level.

- Statistic methods for verification of defined hypotheses.

- Monitoring of research work.

\section{Elementary schools research results}

Research results were evaluated, statistically processed and they are presented here

Graph No.1 in the form of curves of development. Graph No. 1 shows the development of technical creativity (imagination) defined with the help of Construction and shape test; graph No. 2 shows the development of creative thinking. Torrance figural test of creative thinking was used here.

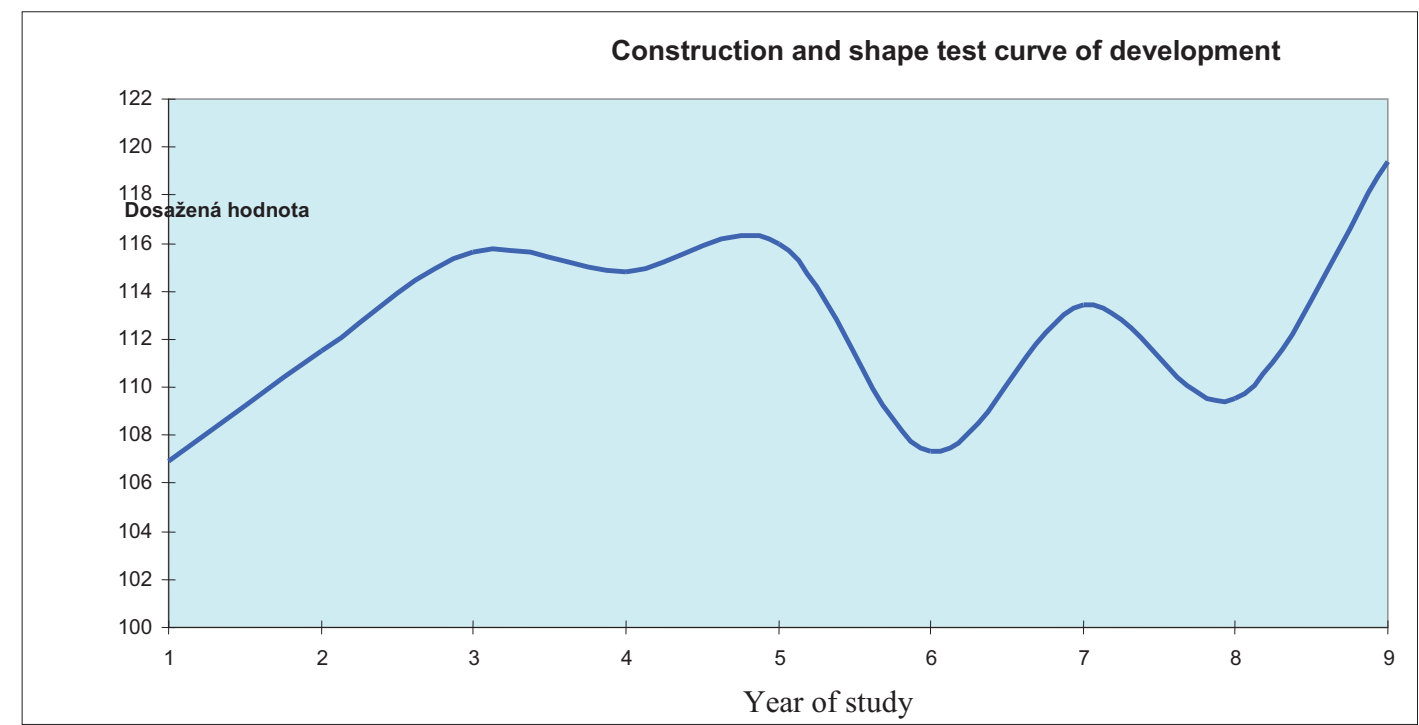

Graph No. 2

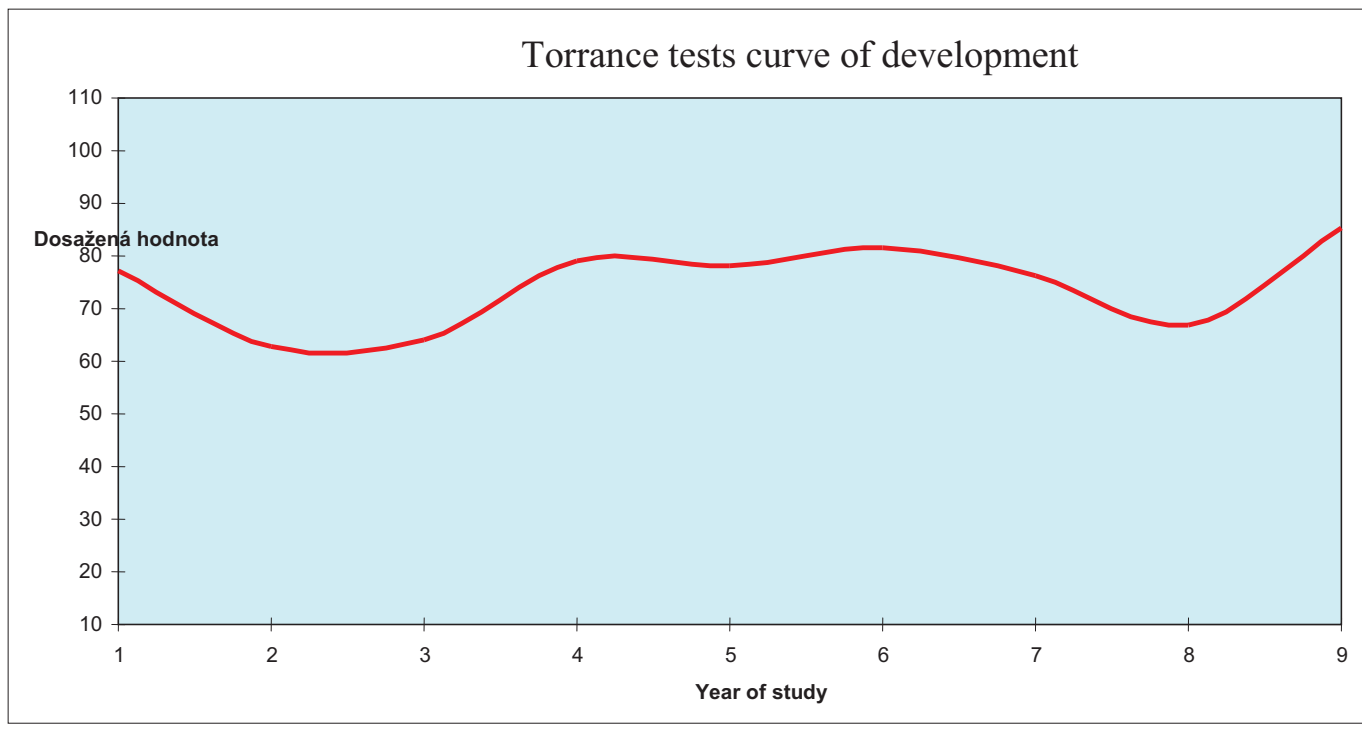

Comparison of the creative thinking development and technical creativity (imagination) development is showed in the graph No. 3 . 


\section{Graph No. 3}

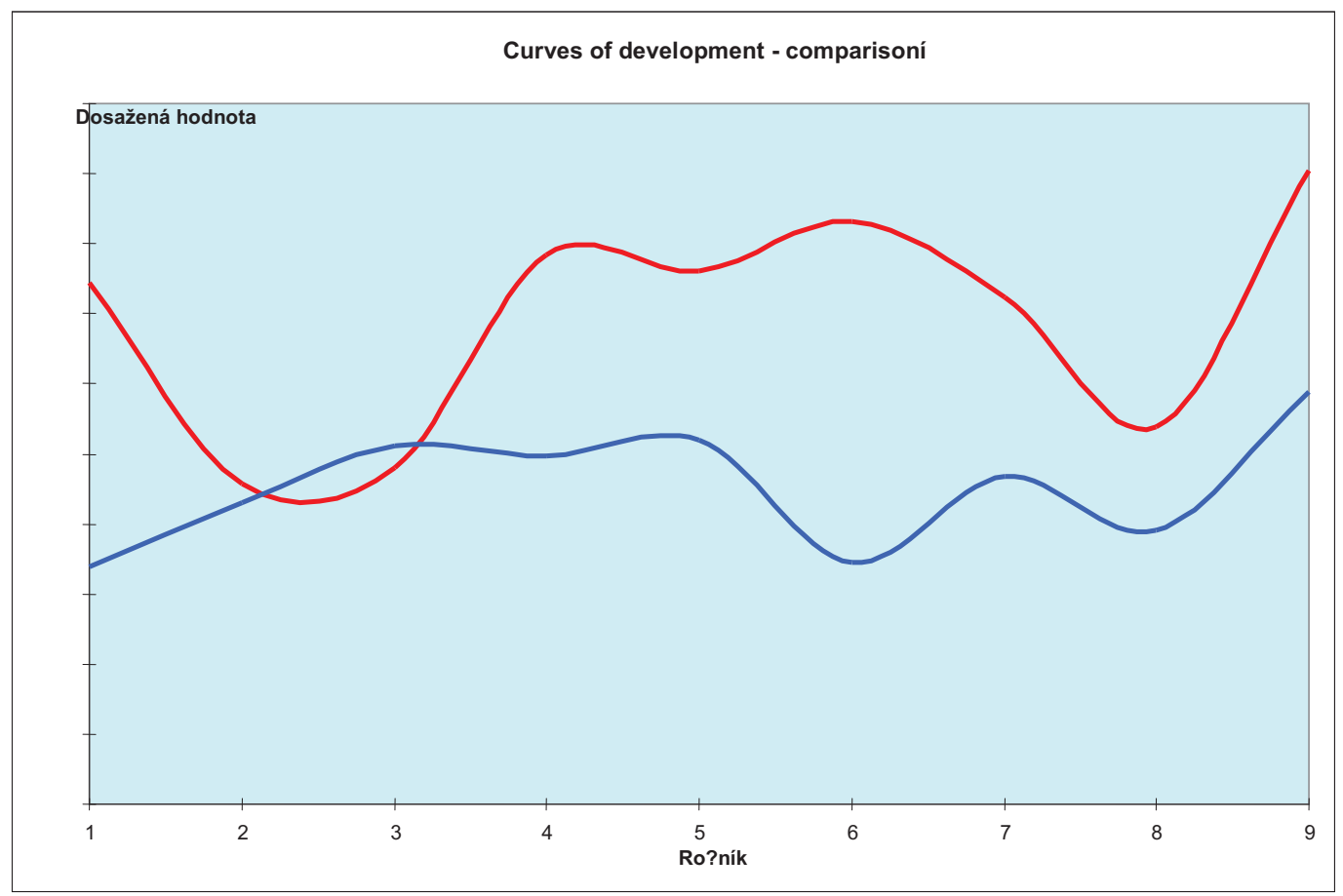

development

... Torrance tests curve of

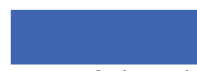

... Construction and shape tests

curve of development

Research results show those respondents (or age groups) who need to be given more tasks of constructive character - the technical creativity (imagination) tasks. The results also show when it is necessary to develop creative thinking or include education projects with problematic elements that lead the students to independent creative thinking.
Creative skills research results concerning all respondents

Teacher's personality largely participates in the development of creative skills. Following curves show the creative skills development of individual age groups - pupils of the $1^{\text {st }}$ stage of elementary schools, pupils of the $2^{\text {nd }}$ stage of elementary schools, faculty of education students and experienced teachers. Graph No. 4 shows the development of technical creativity tested by the Torrance construction task test, graph No. 5 show the development of creative thinking. We used the Torrance figural test of creative thinking for this research.

\section{Graph No. 4}

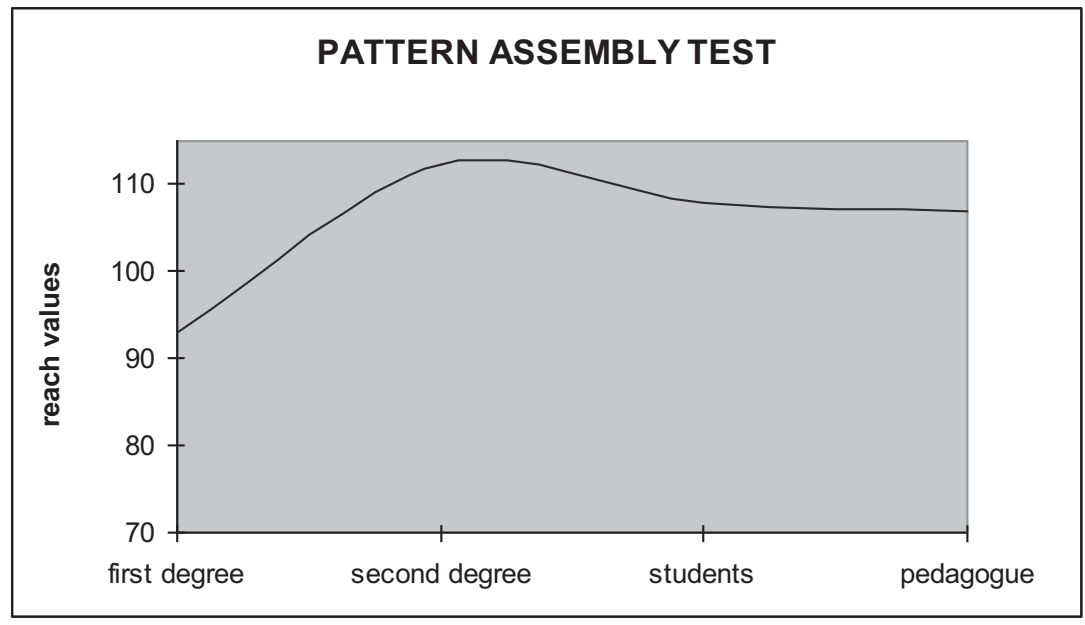


Graph No. 5

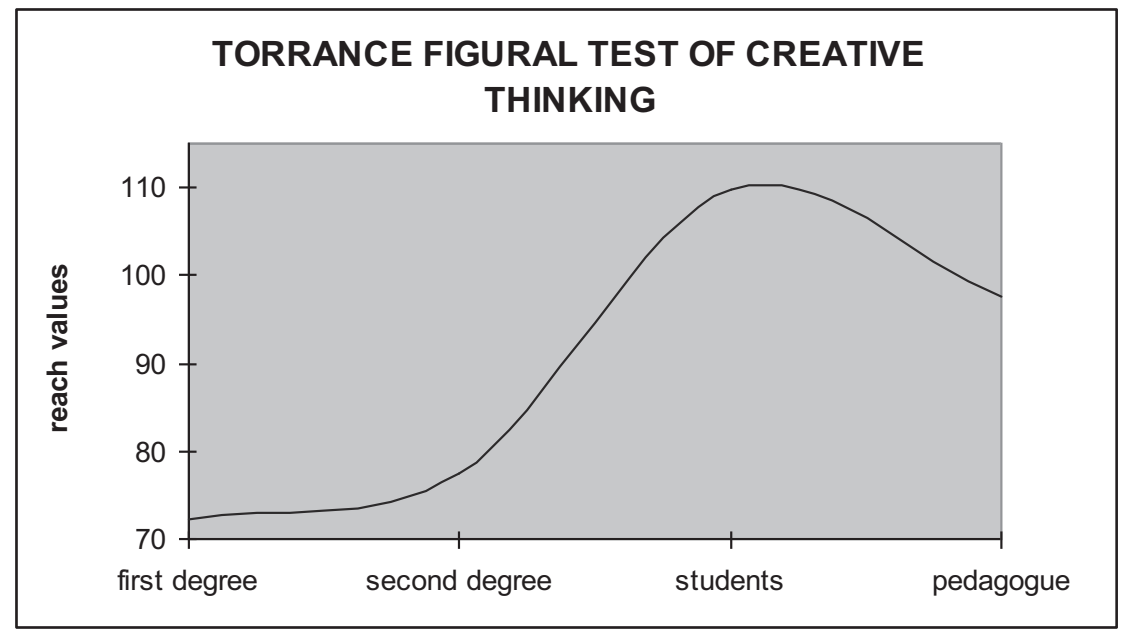

The last graph shows the comparison of technical creativity and creative thinking in the individua groups.

Graph No.6

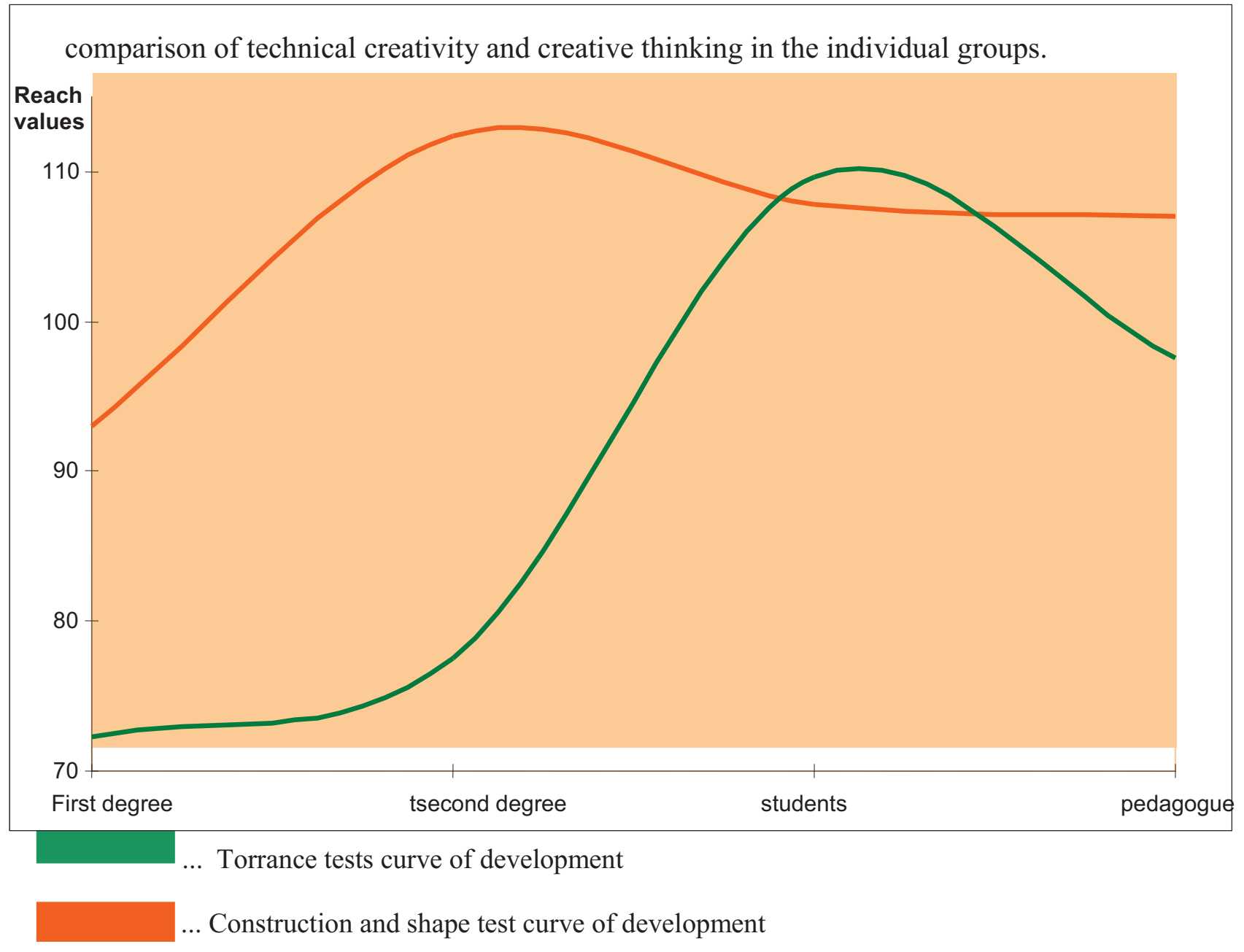


This implies that the high values in technical creativity were reached by the students of the 2 nd stage of elementary schools. However, the academic students showed high creative thinking.

Measuring data in both tests were statistically processed and the results were presented in specialized publications.

\section{Study programmes innovation, change of the management and work style at elementary schools}

Research, concerning the students and teachers creative skills level at elementary schools and faculties of education, mapped how creative our young generation is. In order to reach the high level of creative skills within whole population, it is necessary to start with the youngest. We need to change the style of work at our elementary schools, open the schools for the outside world, lead our children to independent thinking, and develop their technical thinking from the very beginning of their lives. This is the only way how the technical disciplines can present the specialists of high quality in the future.

Main goal of the project under the name Nonverbal creativity in technical education was to create an educational programme for creative teaching of technical education at our elementary schools - Creative technical work. There was an optional subject integrated to pedagogic study programmes under similar name. The research also shows that the teaching goals like creativity and adaptation are nowadays specified by teachers as very important in education programmes, but the practice is usually very different. If the activities in the education field Man and the world of work should develop creative thinking and imagination, they need to be worked out mainly as problem-solving tasks and teaching projects. All-school teaching projects are usually very effective.

Tasks for creative skills development include the programme called Creative technical work, labelled as CTW (in Czech language TTPTvorive technicke prace).

C- Creative thinking - new ideas in working with different materials, active participation, independence, terminology, utilisation of crafted products;
T - Technical imagination - constructive tasks, assembly and dismantling work;

$\mathbf{P}$ - Projects and problems - their realisation in technical education, interconnection of gained knowledge and skills within the project realisation, problem solving.

\section{Summary}

Creativity forms the basis of not only the intellectual success, when it helps to produce surprising and original ideas, but also the practical success, when we put these ideas into practice. We should not be afraid of being flexible and original or changing the oldfashioned standards and traditional views on solving problems. We should use any opportunity to be creative and create a stimulating environment for such activities. Only this way we, as well as the students of elementary schools, can use the creative potential that the nature invested to us. Human brain is still much more powerful than any computer. It just needs to be switched on.

\section{References}

[1] BUZAN, T. Mentální mapování. - 1. vyd. Praha: Portál, 2007. ISBN 978-80-7367-200-3.

[2] CAGÁŇOVÁ, D. - RUSKOVÁ, D.: Tvorivé metódy $s$ divergentným systémom myslenia vo výučbe cudzích jazykov. Divergent creative thinking methods in foreign language teaching. In: Vedecké práce MtF STU v Bratislave so sídlom v Trnave. - ISSN 1336-1589. - Č. 20 (2006), s. 33-37

[3] HONZÍKOVÁ, J.; MACH, P.; NOVOTNÝ, J. a kol. Alternativní prístupy $k$ technické výchově. - 1. vyd. Plzeň: ZČU, 2007.

[4] HONZÍKOVÁ, J. Nonverbální tvořivost $v$ technické výchově. - 1. vyd. Plzeň: ZČU, 2008. 102 s. + CD. ISBN 978-80-7043-714-8.

Doc. PaedDr. Jarmila Honzíková, Ph.D.

University of West Bohemia in Pilsen

Faculty of education

Department of technical education

Veleslavinova 42

30614 Pilsen, Czech Republic

Phone number.: +420 377636503

E-mail: jhonziko@kat.zcu.cz 